\title{
Systematic review and meta-analysis of the relationship between sleep disorders and suicidal behaviour in patients with depression
}

\author{
Xiaofen Wang, Sixiang Cheng and Huilan Xu* (1)
}

\begin{abstract}
Background: The potential link between sleep disorders and suicidal behaviour has been the subject of several reviews. We performed this meta-analysis to estimate the overall association between sleep disorders and suicidal behaviour and to identify a more specific relationship in patients with depression.

Methods: A systematic search strategy was developed across the electronic databases PubMed, EMBASE and the Cochrane Library from inception to January 1, 2019 for studies that reported a relationship between sleep disorders and suicidal behaviour in depressed patients. The odds ratio (OR) and corresponding 95\% confidence interval (Cl) were used to measure the outcomes. Heterogeneity was evaluated by Cochran's $Q$ test and the $I^{2}$ statistic. The Newcastle-Ottawa Scale (NOS) was adopted to evaluate the methodological quality of each of the included studies, and the Grading of Recommendations Assessment, Development and Evaluation (GRADE) approach was used to assess the quality of the evidence. We calculated the overall association between sleep disorders and suicidal behaviour and estimated more specific categories, including insomnia, nightmares, hypersomnia, suicidal ideation, suicide attempt, and completed suicide.

Results: A total of 18 studies were included in this study. Overall, sleep disorders were closely related to suicidal behaviour in patients with depression $(\mathrm{OR}=2.4595 \% \mathrm{Cl}: 1.334 .52)$. The relatively increased risks of sleep disorders with suicidal ideation, suicide attempt and completed suicide ranged from 1.24 (95\% Cl: 1.00 1.53) to 2.41 (95\% Cl: 1.45 4.02). Nightmares were found to be highly correlated with the risk of suicidal behaviour ( $\mathrm{OR}=4.4795 \% \mathrm{Cl}$ : 2.00 9.97), followed by insomnia ( $\mathrm{OR}=2.2995 \% \mathrm{Cl}: 1.69$ 3.10). The certainty of the evidence was rated as very low for the overall outcome and the major depression subgroup and was rated as low for the depression subgroup.

Conclusions: This meta-analysis supports the finding that sleep disorders, particularly nightmares and insomnia, increase the risk of suicidal behaviour in depressed patients. Considering that all included studies were observational, the quality of the evidence is rated as very low. More well-designed studies are needed to confirm our findings and to better explain the mechanisms by which sleep disorders aggravate suicidal behaviour in depressed patients.
\end{abstract}

Keywords: Sleep disorder, Suicidal behaviour, Depression, Systematic review, Meta-analysis

\footnotetext{
* Correspondence: xhl1120131@163.com

Department of Social Medicine and Health Management, Xiangya School of

Public Health, Central South University, NO.238 Shang Ma Yuan Ling Road,

Kaifu District, Changsha 410078, Hunan Province, China
}

(c) The Author(s). 2019 Open Access This article is distributed under the terms of the Creative Commons Attribution 4.0 International License (http://creativecommons.org/licenses/by/4.0/), which permits unrestricted use, distribution, and reproduction in any medium, provided you give appropriate credit to the original author(s) and the source, provide a link to the Creative Commons license, and indicate if changes were made. The Creative Commons Public Domain Dedication waiver (http://creativecommons.org/publicdomain/zero/1.0/) applies to the data made available in this article, unless otherwise stated. 


\section{Background}

Suicide is a major public health problem worldwide. Globally, it is estimated that more than 800,000 people died of suicide in 2012, and more than 1 million people died of suicide in 2016 [1, 2]. In the United States, suicide is the second most common cause of death in people aged 15 34 years old. Similarly, in China, suicide is the leading cause of death in people in the same age group [3]. Millions of individuals are bereaved by suicide every year, and suicide prevention has overwhelming significance for global public health. The Institute of Medicine (IOM) has made suicide prevention a top priority and called for measures to explore evidencebased risk factors to reduce national suicide rates [4]. To date, many risk factors have been described, including unchangeable and potentially changeable factors. Unchangeable factors include age, gender, and severe physical illness, whereas changeable factors include previous suicide attempts, harmful use of alcohol and insomnia symptoms [5-7]. Among these factors, global or partial insomnia is an important risk factor for suicidal behaviour, but it has generally been overlooked in previous reviews of suicide risk factors and suicide prevention $[8,9]$.

Depressive disorders are the most prevalent mental illness and a well-established risk factor for suicidality [10]. According to the World Health Organization (WHO), 350 million people worldwide suffer from depression, and major depression is expected to be a major cause of disability by $2030[11,12]$. Additionally, the suicide rate in depressed patients is reported to be 22 to 36 times higher than that in the general population [13]. The incidence of suicidal ideation in patients with major depression is approximately $11 \%$ 63\% [14], among which $15 \%$ have recurrently attempted suicide [15]. People with depression present many physical symptoms in addition to the diagnostic criteria, such as somatic pain, gastrointestinal symptoms and sleep disorders [16]. Sleep disorders, particularly insomnia, are reported to be a core symptom of depression and double the risk of developing depression [17]. Severe insomnia in the diagnosis of depression has been confirmed as one of the few clinical predictors of suicide in the first year of follow-up [18].

Numerous studies have shown that both depression and sleep disorders are independent risk factors for suicidal behaviour. Do sleep disorders increase the risk of suicidal behaviour in depressed patients? Epidemiological evidence remains controversial. Some studies have shown that suicide in depressed patients is mainly caused by the clinical symptoms of the disease itself and have proposed a genetic hypothesis based on animal experiments $[19,20]$. Through a national survey, Fang et al. found that both late insomnia and hypersomnia were strongly associated with suicidal ideation in the first episode of major depression in Chinese patients [21]. However, Chellappa et al. confirmed that only insomnia was associated with suicidal intention after controlling for age and gender [18]. Conversely, Li et al. reported that nightmares had a significant association with suicidal behaviour, and the link between insomnia and suicide disappeared in multivariate analysis [22]. According to Gallagher et al., sleep disorders in depressed patients were significantly associated with a higher risk of completed suicide after adjusting for age and gender but not after fully adjusting for other variables [23].

Considering the high suicide rate and high prevalence of sleep disorders in patients with depression, we conducted this systematic review and meta-analysis to address the disagreement between several previous research articles and to provide valuable information for clinical practice by exploring the risk difference between various sleep disorders and suicidal behaviours.

\section{Methods}

Based on the Systematic and Meta-analytical Preferred Reporting Program (PRISMA) [24], a prospective protocol involving objectives, search strategies, inclusion and exclusion criteria, outcomes and methods of system analysis was developed before our implementation of this study. The detailed PRISMA checklist can be found in Additional file 1: Table S1.

\section{Literature search strategy}

A systematic search strategy with no language, geographical, or publication-type restrictions was developed in January 2019. Our search consisted of two steps. First, we searched the electronic databases PubMed, EMBASE and the Cochrane Library from inception to January 1, 2019. We used the following Medical Subject Headings $(\mathrm{MeSH})$ terms and their combinations of free words to search: sleep disorders/sleep arousal disorders/sleep deprivation//sleep wake disorders/sleep initiation and maintenance disorders, depressive disorder/depression/ mental disorders, and suicidal behaviour/suicide ideation/suicide attempt/suicide. Second, we implemented a manual search based on the reference lists of the articles included in the first step and contacted the authors via email to obtain unpublished data. We supplemented the results of electronic searches with manually searched comments, reviews, and conference abstracts. The detailed search strategy can be found in Additional file 1: Table S2. The entire search was independently performed by two reviewers (XFW \& SXC).

\section{Study selection and data extraction}

We included all observational studies that reported an association between sleep disorders and suicidal behaviour in patients with depression. "Depression" in this study referred to the definition of the diagnosis of depression (including major depression) according to internationally 
recognized diagnostic tools, excluding patients with depressive symptoms but diagnosed with mental illnesses other than depression, such as bipolar disorder. If the original study clarified that the patient's diagnosis was depression, our default assumption was that they had excluded a disorder such as bipolar disorder that needed to be excluded in the diagnosis of depression. According to the inclusion criteria of the original studies, if the author reported major depressive disorder (MDD) or indicated that the subject's depression was severe, we assigned this study to the "major depression" group. If the author only mentioned depression and did not report the severity of the patient's depression, we assigned the study to the "depression" group. The classification of sleep disorders was broad and included insomnia, hypersomnia, nightmares, and various sleep problems defined by the authors in their original studies, such as low sleep quality, short sleep duration, and low habitual sleep efficiency. Suicidal behaviour in this meta-analysis included suicidal ideation, suicide attempt and completed suicide. Studies were excluded if they (a) studied an irrelevant topic, used an unavailable population or had incomplete data, (b) were reviews, conference abstracts, editorial letters, qualitative research or animal model papers, or (c) were duplicated reports. If there were duplicate studies, the most recent or most complete version was selected. If multiple languages were used to describe and publish the same data, the English version was selected. We extracted data on the first author, year of publication, country of origin, study design, participant numbers and characteristics, exposure and outcomes and their measurement tools. The data from all included studies were extracted and reviewed independently by XFW and SXC. Any dispute or disagreement between the two reviewers that could not be agreed upon was arbitrated by a third reviewer (HLX).

\section{Assessment of risk of bias and grading the evidence}

The methodological quality of all included studies was independently assessed using the modified version of the Newcastle-Ottawa Scale (NOS) [25]. Potential risk of bias was identified by five items, including representativeness of the subjects, diagnosis of depression, adjustment for confounders, ascertainment of outcomes and reporting loss to follow-up. The risk of each item was identified as "low risk", "high risk" or "unclear risk". Low risk was recorded as " 1 point", and the other two types of risk were recorded as "0 points". A study with a total score of 3 points or above indicated a lower risk of bias.

Confidence in the estimate for the outcome was determined by the Grading of Recommendations Assessment, Development and Evaluation (GRADE) approach [26]. This assessment was performed by GRADEpro software (version 3.2, Evidence Prime, Hamilton, ON, Canada, 2015) [27]. The rating criteria were based on risk of bias, inconsistency, indirectness, imprecision, publication bias and other considerations. Because all included studies in this meta-analysis were observational studies, the quality of the evidence was initially defined as low. However, the rating could be upgraded to high (a) if the magnitude of the treatment effect was large (relative risk $(R R)>2$ or $R R<0.5)$ or very large $(R R>5$ or $R R<0.2)$, (b) if there was evidence of a dose-response relation or (c) if all plausible biases could decrease the magnitude of an apparent treatment effect. In addition, according to the handbook of GRADE, because inconsistency in this study could be explained by differences in populations (depression vs. major depression), we analysed, presented and graded the quality of the evidence by stratifying according to this variable.

\section{Outcomes and statistical analysis}

The result of interest was the relationship between sleep disorders and suicidal behaviour. Sleep disorders included insomnia, nightmares, and hypersomnia; no specific sleep disorder was classified as "other". Suicidal behaviour included suicidal ideation, suicide attempt and completed suicide. Studies that did not specifically address suicidal behaviour were also classified as "other". The association between sleep disorders and suicidal behaviour was expressed as the odds ratio (OR). We obtained the ORs and corresponding 95\% confidence intervals (CI) from most of the included studies. If those values were not directly available, we calculated the OR and $95 \% \mathrm{CI}$ with the coefficient estimates and standard errors mentioned in the text.

The statistical analysis was conducted using Stata 12.0 (College Station, TX: StataCorp LP) and RevMan 5.3 (Cochrane Collaboration, Copenhagen, Denmark). Outcomes were assessed by pooled logOR among all included studies, and the corresponding 95\% CIs were calculated by a fixed effects model or a random effects model. Statistical heterogeneity was defined by Cochran's $\mathrm{Q}$ test with a $P$ value $<0.1$ or an $\mathrm{I}^{2}$ value $>50 \%$, and a random effects model was used for subsequent analysis. Conversely, when the $P$ value was $>0.1$ or the $\mathrm{I}^{2}$ value was $<50 \%$, a fixed effects model was used. To explore potential sources of heterogeneity, meta-regression and subgroup analyses were implemented through several categories: year of publication (1997 2010 vs. $2010 \sim 2019)$, study design (retrospective vs. prospective vs. cross-sectional), sample size $(<1000$ vs. $>1000)$, age of subjects $($ mean $<40 v s$. mean $\geq 40$ ), diagnostic outcome (major depression $v s$. depression), diagnostic criteria (ICD-10 vs. DSM-III-R vs. DSM-IV vs. CES-D), sleep disorder type (insomnia $v s$. nightmares $v s$. hypersomnia $v s$. other), and suicidal behaviour type (suicidal ideation vs. suicide attempt vs. completed suicide $v s$. other). Potential publication bias was detected by testing the asymmetry of the funnel plot and 
performing an Egger's linear regression test. Sensitivity analysis was determined by excluding studies with a relatively high risk of bias and comparing the results to previous effect values. $P<0.05$ was considered statistically significant in all analyses.

\section{Results}

\section{Study identification and selection}

A total of 1634 studies were identified through a preliminary database search, and 293 duplicates were excluded from Endnote X8 (Thomson Reuters, MI). By browsing the titles and abstracts, 132 studies were available and entered full-text screening. After reading these documents carefully, 114 studies were excluded (68 had data that were not extractable, 19 were reviews or conference abstracts, 15 were editorial letters, 9 were qualitive research studies, and 3 full texts could not be obtained). Finally, a total of 18 eligible studies were included in this meta-analysis. The detailed research identification and selection are shown in Fig. 1.

\section{Study characteristics}

The 18 studies were published between 1997 and 2019, covering a total of 198,893 participants whose mean ages in each study ranged from $12.5(\mathrm{SD}=3.1)$ to 48.1 years
(SD =15.6). There were 6 retrospective studies, 6 prospective studies and 6 cross-sectional studies. The sample sizes in each study varied from 41 to 163,512, and all patients were formally diagnosed with depression or major depression. Regarding the diagnostic criteria, the Diagnostic and Statistical Manual of Mental Disorders (DSM) was used in most studies (15), including the DSM-III-R (4) and the DSM-IV (11); the International Classification of Diseases, Tenth Revision (ICD-10) was adopted in two studies; and the Center for Epidemiology Scale for Depression (CES-D) was used in one study. The sleep disorders we included were hypersomnia, insomnia, sleep quality, etc. The sleep measures in these studies varied considerably, with most studies using stable scales (11). A few of the studies used questionnaires produced by the authors themselves (4), and two studies used a combination of a maturity scale and a homemade questionnaire. Of these studies, 13 provided ORs for sleep disorders and suicidal ideation, 7 reported ORs for sleep disorders and suicide attempt, and only 2 studies showed the results of sleep disorders and completed suicide. Moreover, 17 studies reported patient characteristics and the risk between sleep disorders and suicidal behaviours for both male and female subjects, whereas one study only reported female subjects' relevant

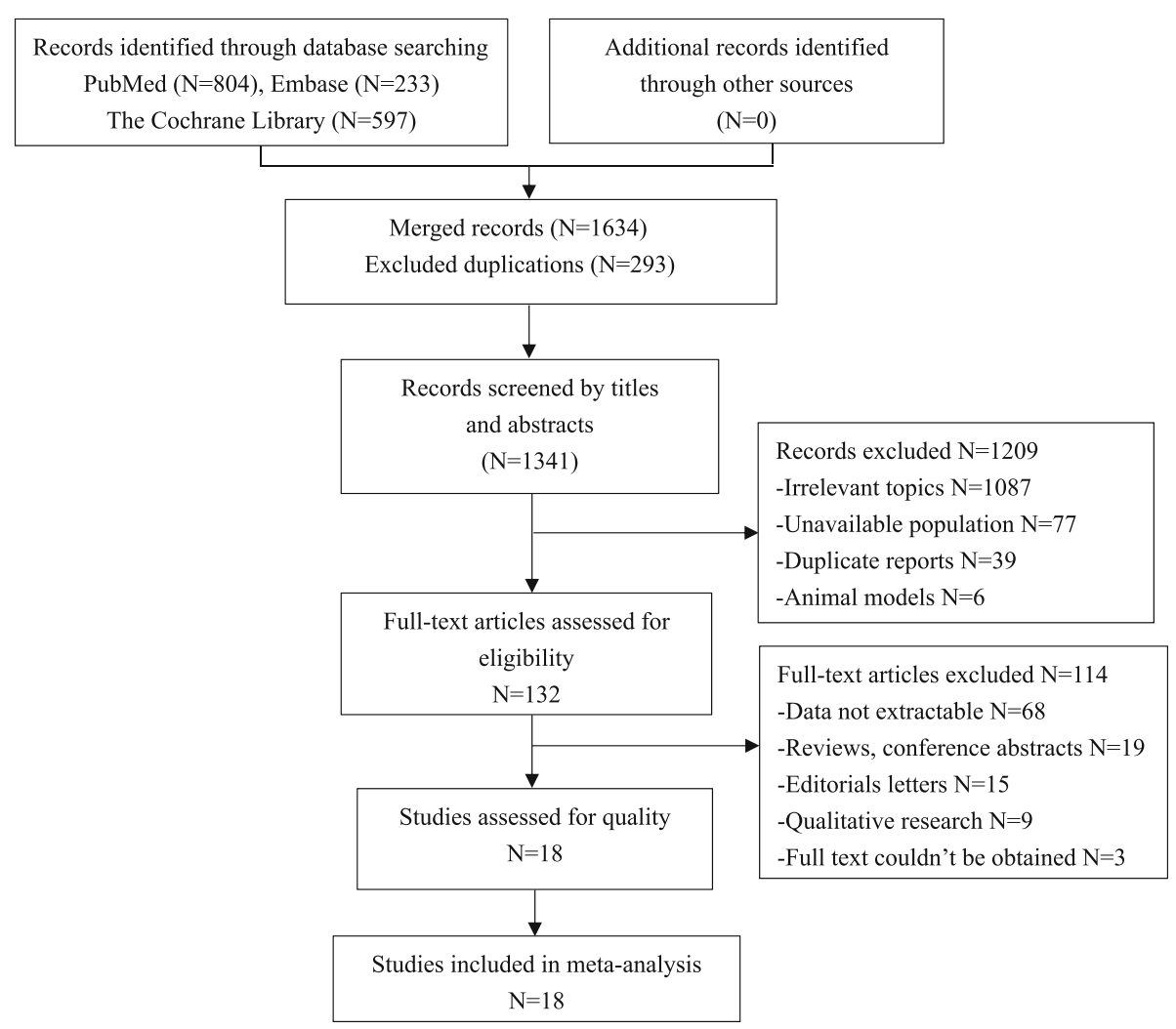

Fig. 1 Flow diagram of included/excluded studies. A total of 1634 documents were found in the initial search. After removing duplicates, reading titles, abstracts and full texts, and evaluating the quality of the articles, 18 eligible studies were included and analysed 
outcomes. The characteristics of the included studies are shown in Table 1.

\section{Evaluation of risk of bias}

The risk of bias varied across the included studies. We found that most studies showed a low risk of bias in the representativeness of subjects (17) and the diagnosis of depression (18). Three studies did not control for confounding factors; thus, they were identified as "high risk" for this item. Fifteen studies were considered to have a low risk of bias in the ascertainment of outcomes due to their objective outcomes. However, only five studies reported follow-up and loss of follow-up, and similar information was not available in most studies (10). Overall, the included studies could be identified as having a low risk of bias because their NOS scores were 3 points or above. The details of the methodology for bias assessment in the overall study and for each study are shown in Fig. 2.

\section{Outcome and subgroup analysis}

After combining the ORs reported in the 18 included studies, we found that sleep disorders were associated with a significant risk of suicidal behaviour across all depressed patients in the random effects model. The pooled OR was 2.45 (95\% CI: 1.33 4.52), and substantial heterogeneity was detected $\left(\mathrm{I}^{2}=99.1 \% . P<0.001\right)$ (Fig. 3). The meta-regression analysis showed that the $\mathrm{R}^{2}$ of the depression diagnostic outcome and suicidal behaviour type was $39.99 \%(P=0.011)$ and $48.39 \%(P=$ $0.003)$, respectively. These variables were the cause of partial heterogeneity among studies; that is, a depression diagnosis could explain $39.99 \%$ of the heterogeneous sources, and the type of suicidal behaviour could explain $48.39 \%$ of the heterogeneous sources. The year of publication, study design, sample size, age of subjects, diagnostic criteria and sleep disorder type failed to explain the heterogeneity among studies $(P>$ 0.05) (Additional file 1: Table S3).

In the subgroup analysis, we found that patients diagnosed with major depression ( $\mathrm{OR}=2.92$, 95\% CI:1.42 5.98) had a higher risk of suicidal behaviour than those diagnosed with depression $(\mathrm{OR}=1.41,95 \% \mathrm{CI}: 1.141 .73)$. Studies with the DSM-III-R as diagnostic criteria (OR = 4.80, 95\% CI: 2.90 7.67) showed a higher risk of suicidal behaviour, followed by those with the ICD-10 (OR = 2.13, 95\% CI: 1.104 .12$)$ and the DSM-IV $(\mathrm{OR}=2.11$, 95\% CI: 0.964 .65$)$. For the variable "sleep disorder type", we found that insomnia (OR $=2.29,95 \%$ CI:1.69 3.10) and nightmares $(\mathrm{OR}=4.47,95 \% \mathrm{CI}: 2.00$ 9.97) were significantly associated with an increased risk of suicidal behaviour. This relationship was not found for hypersomnia or other types of sleep disorders. Analysis based on the "suicidal behaviour type" subgroup showed that sleep disorders had a significant risk association with suicidal ideation $(\mathrm{OR}=2.32,95 \% \mathrm{CI}: 1.114 .88)$ and suicide attempt (OR $=2.41,95 \% \mathrm{CI}: 1.45$ 4.02). This association also existed with completed suicide but at the margin of error $(P=0.05)$. In addition, cross-sectional studies published between 1997 and 2010 and with a sample size $<1000$ as well as with a mean age of patients $<40$ detected a higher risk of suicidal behaviour. The details of the subgroup analysis are shown in Table 2.

\section{Publication bias and sensitivity analysis}

There was visible asymmetry in the funnel plots, and Egger's test was $-2.17(P=0.045)$. Combining the results of both analyses, we inferred that there was evidence of publication bias in this meta-analysis (Additional file 1: Figure S1).

Sensitivity analysis was performed after excluding five studies with a relatively high risk of bias. The pooled OR was 2.31 (95\% CI: 1.12 4.77), which was slightly but not significantly lower than the previous pooled OR (OR = 2.45 95\% CI: 1.33 4.52), indicating the stable and trustworthy nature of our analysis.

\section{GRADE assessment}

The quality of the evidence was rated as very low for the association between sleep disorders and suicidal behaviour in the overall outcome and in the major depression subgroup. This evidence quality was increased by one point because the magnitude of the effect was large (OR $>2$, based on consistent evidence from at least two studies with no plausible confounders). However, due to the substantial heterogeneity among studies and because publication bias was detected, which subtracted two points, the final score was one point, which represented a quality level of "very low". Additionally, the evidence was assessed as low for the outcome of the depression subgroup. As with the status of evidence at the beginning of observational studies, no significant upgrade or downgrade factors were detected (Table 3 ).

\section{Discussion}

This work is the first meta-analysis to specifically assess the association between sleep disorders and suicidal behaviours in individuals with depression. Our evidence showed that patients with sleep disorders had a higher risk of suicidal behaviour than those without sleep disorders, and the more severe the depression was, the higher the risk of suicidal behaviour. Patients with sleep disorders were found to be more likely to exhibit various suicidal behaviours, including suicide ideation, suicide attempt and completed suicide. However, only insomnia and nightmares were found to be statistically associated with an increased risk of suicidal behaviour. 
Table 1 Characteristics of included studies

\begin{tabular}{|c|c|c|c|c|c|c|c|c|c|c|}
\hline Author & Country & Study design & $\begin{array}{l}\text { Sample } \\
\text { size }\end{array}$ & Diagnoses & $\begin{array}{l}\text { Diagnostic } \\
\text { criteria }\end{array}$ & $\begin{array}{l}\text { Age } \\
\text { (years) }\end{array}$ & $\begin{array}{l}\text { Sleep } \\
\text { disturbance }\end{array}$ & Sleep measure & $\begin{array}{l}\text { Suicide } \\
\text { outcome }\end{array}$ & Adjustments \\
\hline $\begin{array}{l}\text { Agargun } \\
\text { et al. } 1997 \\
\text { [28] }\end{array}$ & Turkey & Retrospective & 113 & $\begin{array}{l}\text { Major } \\
\text { depression }\end{array}$ & DSM-III-R & $\begin{array}{l}\text { 18 70 } \\
\text { Mean: } \\
32.6\end{array}$ & $\begin{array}{l}\text { Hypersomnia, } \\
\text { insomnia }\end{array}$ & SADS & $\begin{array}{l}\text { Suicidal } \\
\text { ideation }\end{array}$ & NA \\
\hline $\begin{array}{l}\text { Agargun } \\
\text { et al. } 1997 \\
\text { [29] }\end{array}$ & Turkey & Prospective & 41 & $\begin{array}{l}\text { Major } \\
\text { depression }\end{array}$ & DSM-III-R & $\begin{array}{l}34.6 \pm \\
10.8\end{array}$ & $\begin{array}{l}\text { Sleep quality, } \\
\text { sleep latency, } \\
\text { sleep } \\
\text { duration, } \\
\text { habitual sleep } \\
\text { efficiency }\end{array}$ & PSQI & $\begin{array}{l}\text { SADS } \\
\text { suicidality } \\
\text { score }\end{array}$ & NA \\
\hline $\begin{array}{l}\text { Li et al. } 2012 \\
\text { [22] }\end{array}$ & Hong Kong & Prospective & 419 & $\begin{array}{l}\text { Major } \\
\text { depression }\end{array}$ & ICD-10 & $\begin{array}{l}44.6 \pm \\
10.4\end{array}$ & $\begin{array}{l}\text { Nightmares, } \\
\text { insomnia }\end{array}$ & $\begin{array}{l}\text { Sleep } \\
\text { questionnaire, } \\
\text { NDQ }\end{array}$ & $\begin{array}{l}\text { Suicidal } \\
\text { ideation }\end{array}$ & Yes \\
\hline $\begin{array}{l}\text { Lopes et al. } \\
2016 \text { [30] }\end{array}$ & Brazil & $\begin{array}{l}\text { Cross- } \\
\text { sectional }\end{array}$ & 214 & $\begin{array}{l}\text { Major } \\
\text { depression }\end{array}$ & DSM-IV & $\begin{array}{l}12.5 \pm \\
3.1\end{array}$ & $\begin{array}{l}\text { Early } \\
\text { awakening, } \\
\text { night } \\
\text { awakening, } \\
\text { initial } \\
\text { insomnia, } \\
\text { daytime } \\
\text { sleepiness }\end{array}$ & DICA-IV & $\begin{array}{l}\text { Suicidal } \\
\text { ideation, } \\
\text { suicide } \\
\text { attempts, } \\
\text { suicide } \\
\text { behavior, } \\
\text { suicidal plan }\end{array}$ & Yes \\
\hline $\begin{array}{l}\text { Yoshimasu } \\
\text { et al. } 2006 \\
\text { [31] }\end{array}$ & Japan & $\begin{array}{l}\text { Cross- } \\
\text { sectional }\end{array}$ & 231 & $\begin{array}{l}\text { Major } \\
\text { depression }\end{array}$ & DSM-IV & $\begin{array}{l}36.3 \pm \\
14.8\end{array}$ & $\begin{array}{l}\text { Insomnia, } \\
\text { overall sleep } \\
\text { disorders }\end{array}$ & $\begin{array}{l}\text { Patients' three } \\
\text { most painful } \\
\text { complaints, } \\
\text { SDS, KMI }\end{array}$ & $\begin{array}{l}\text { Suicidal } \\
\text { ideation }\end{array}$ & Yes \\
\hline $\begin{array}{l}\text { Agargun } \\
\text { et al. } 1998 \\
\text { [32] }\end{array}$ & Turkey & Prospective & 63 & $\begin{array}{l}\text { Major } \\
\text { depression }\end{array}$ & DSM-III-R & $\begin{array}{l}34.1 \pm \\
10.9\end{array}$ & Nightmares & PSQI & $\begin{array}{l}\text { Suicidal } \\
\text { ideation }\end{array}$ & NA \\
\hline $\begin{array}{l}\text { Sit et al. } 2015 \\
\text { [33] }\end{array}$ & $\begin{array}{l}\text { United } \\
\text { States }\end{array}$ & Retrospective & 628 & Depression & DSM-IV & $\begin{array}{l}28.7 \pm \\
6.00\end{array}$ & $\begin{array}{l}\text { Sleep } \\
\text { disturbance }\end{array}$ & SIGH-ADS & $\begin{array}{l}\text { Suicidal } \\
\text { ideation }\end{array}$ & Yes \\
\hline $\begin{array}{l}\text { Yoshimasu } \\
\text { et al. } 2006 \\
\text { [34] }\end{array}$ & Japan & $\begin{array}{l}\text { Cross- } \\
\text { sectional }\end{array}$ & 199 & $\begin{array}{l}\text { Major } \\
\text { depression }\end{array}$ & DSM-IV & $\begin{array}{l}38.4 \pm \\
16.5\end{array}$ & $\begin{array}{l}\text { Sleep } \\
\text { disorders }\end{array}$ & $\begin{array}{l}\text { Patients' chief } \\
\text { complaints, } \\
\text { KMI, SDS }\end{array}$ & $\begin{array}{l}\text { Suicidal } \\
\text { ideation }\end{array}$ & Yes \\
\hline $\begin{array}{l}\text { Agargun } \\
\text { et al. } 2007 \\
\text { [35] }\end{array}$ & Turkey & Retrospective & 100 & $\begin{array}{l}\text { Major } \\
\text { depression }\end{array}$ & DSM-IV & $\begin{array}{l}32.1 \pm \\
10.7\end{array}$ & $\begin{array}{l}\text { Nightmares, } \\
\text { insomnia }\end{array}$ & ICSD-R, HDRS & $\begin{array}{l}\text { Suicide } \\
\text { attempts }\end{array}$ & Yes \\
\hline $\begin{array}{l}\text { Stubbs et al. } \\
2016 \text { [36] }\end{array}$ & $\begin{array}{l}\text { United } \\
\text { Kingdom }\end{array}$ & Retrospective & 5701 & Depression & DSM-IV & $\begin{array}{l}43.4 \pm \\
16.6\end{array}$ & $\begin{array}{l}\text { Sleep } \\
\text { disturbance }\end{array}$ & $\begin{array}{l}\text { Self-reported } \\
\text { information }\end{array}$ & $\begin{array}{l}\text { Suicidal } \\
\text { ideation, } \\
\text { suicide } \\
\text { attempts }\end{array}$ & Yes \\
\hline $\begin{array}{l}\text { Gallagher } \\
\text { et al. } 2009 \\
\text { [23] }\end{array}$ & $\begin{array}{l}\text { United } \\
\text { Kingdom }\end{array}$ & Retrospective & $\begin{array}{l}163 \\
512\end{array}$ & Depression & DSM-IV & $\begin{array}{l}39.2 \pm \\
18.0 \\
\text { (Female) }\end{array}$ & Insomnia & NA & $\begin{array}{l}\text { Suicidal } \\
\text { ideation, } \\
\text { suicide } \\
\text { attempts, } \\
\text { completed } \\
\text { suicide }\end{array}$ & Yes \\
\hline $\begin{array}{l}\text { Chellappa } \\
\text { et al. } 2007 \\
\text { [18] }\end{array}$ & Brazil & $\begin{array}{l}\text { Cross- } \\
\text { sectional }\end{array}$ & 70 & $\begin{array}{l}\text { Major } \\
\text { depression }\end{array}$ & DSM-IV & $\begin{array}{l}40.5 \pm \\
12.5\end{array}$ & Insomnia & $S H Q, I C S D$ & $\begin{array}{l}\text { Suicidal } \\
\text { ideation }\end{array}$ & Yes \\
\hline $\begin{array}{l}\text { Park et al. } \\
2016 \text { [37] }\end{array}$ & $\begin{array}{l}\text { Ten Asian } \\
\text { countries/ } \\
\text { area }\end{array}$ & Retrospective & 1122 & Depression & ICD-10 & $\begin{array}{l}48.1 \pm \\
15.6\end{array}$ & Insomnia & NIHCEG & $\begin{array}{l}\text { Suicidal } \\
\text { ideation }\end{array}$ & Yes \\
\hline $\begin{array}{l}\text { Guo et al. } \\
2017 \text { [38] }\end{array}$ & China & $\begin{array}{l}\text { Cross- } \\
\text { sectional }\end{array}$ & 20,130 & Depression & CES-D & $\begin{array}{l}16.3 \pm \\
2.1\end{array}$ & Sleep duration & $\begin{array}{l}\text { Self-reported } \\
\text { information }\end{array}$ & $\begin{array}{l}\text { Suicide } \\
\text { attempts, } \\
\text { suicidal } \\
\text { ideation }\end{array}$ & Yes \\
\hline $\begin{array}{l}\text { Nrugham } \\
\text { et al. } 2008\end{array}$ & Norway & Prospective & 2464 & Depression & DSM-III-R & $\begin{array}{l}13.7 \pm \\
0.5\end{array}$ & Insomnia & KSADS-PL & $\begin{array}{l}\text { Suicide } \\
\text { attempts }\end{array}$ & Yes \\
\hline
\end{tabular}


Table 1 Characteristics of included studies (Continued)

\begin{tabular}{|c|c|c|c|c|c|c|c|c|c|c|}
\hline Author & Country & Study design & $\begin{array}{l}\text { Sample } \\
\text { size }\end{array}$ & Diagnoses & $\begin{array}{l}\text { Diagnostic } \\
\text { criteria }\end{array}$ & $\begin{array}{l}\text { Age } \\
\text { (years) }\end{array}$ & $\begin{array}{l}\text { Sleep } \\
\text { disturbance }\end{array}$ & Sleep measure & $\begin{array}{l}\text { Suicide } \\
\text { outcome }\end{array}$ & Adjustments \\
\hline $\begin{array}{l}\text { McGirr et al. } \\
2007 \text { [40] }\end{array}$ & Canada & Prospective & 156 & $\begin{array}{l}\text { Major } \\
\text { depression }\end{array}$ & DSM-IV & $\begin{array}{l}42.4 \pm \\
13.2\end{array}$ & $\begin{array}{l}\text { Insomnia, } \\
\text { hypersomnia }\end{array}$ & $\begin{array}{l}\text { Psychological } \\
\text { autopsy } \\
\text { method }\end{array}$ & $\begin{array}{l}\text { Completed } \\
\text { suicide }\end{array}$ & Yes \\
\hline $\begin{array}{l}\text { Eikelenboom } \\
\text { et al. } 2018 \\
\text { [10] }\end{array}$ & Netherlands & Prospective & 1713 & $\begin{array}{l}\text { Major } \\
\text { depression }\end{array}$ & DSM-IV & $\begin{array}{l}42.1 \pm \\
12.3\end{array}$ & Insomnia & IRS & $\begin{array}{l}\text { Suicide } \\
\text { attempts }\end{array}$ & Yes \\
\hline $\begin{array}{l}\text { Fang et al. } \\
2019 \text { [21] }\end{array}$ & China & $\begin{array}{l}\text { Cross- } \\
\text { sectional }\end{array}$ & 2017 & $\begin{array}{l}\text { Major } \\
\text { depression }\end{array}$ & DSM-IV & $\begin{array}{l}39.4 \pm \\
12.5\end{array}$ & $\begin{array}{l}\text { Late insomnia, } \\
\text { hypersomnia }\end{array}$ & $\begin{array}{l}\text { A doctor-rating } \\
\text { assessment } \\
\text { questionnaire }\end{array}$ & $\begin{array}{l}\text { Suicidal } \\
\text { ideation }\end{array}$ & Yes \\
\hline
\end{tabular}

Ten Asian countries/area: China, Hong Kong, India, Indonesia, Japan, Korea, Malaysia, Singapore, Taiwan, and Thailand

$D S M$ The diagnostic and statistical manual of mental disorders, SADS Schedule for affective disorders and schizophrenia, HDRS Hamilton depression rating scale, PSQI Pittsburgh sleep quality index, ICD-10 International classification of diseases, tenth revision, NDQ Nightmare distress questionnaire, DICA-IV Diagnostic interview for children and adolescent DSM-IV version, SDS Self-rating depression scale, KMI Kyudai medical inventory, SIGH-ADS Structured interview guide for the Hamilton rating scale for depression, atypical depression symptoms, ICSD-R International classification of sleep disorders-revised, SHQ Sleep habits questionnaire, NIHCEG National Institute for Health and Clinical Excellence Guidelines, CES-D Center for epidemiology scale for depression, IRS Insomnia rating scale, NA Not available

The causality between sleep disorders and suicidal behaviour in depression was not determined. Several hypotheses have been proposed in previous studies that might help explain the underlying mechanisms. Most researchers believe that the activity of 5- hydroxytryptamine (5-HT) is a major candidate for the cause of this association $[29,41] .5$-HT is an important neurotransmitter that promotes wakefulness and the onset of sleep by continuously inhibiting slow-wave sleep (SWS) and rapid eye movement sleep (REM), and

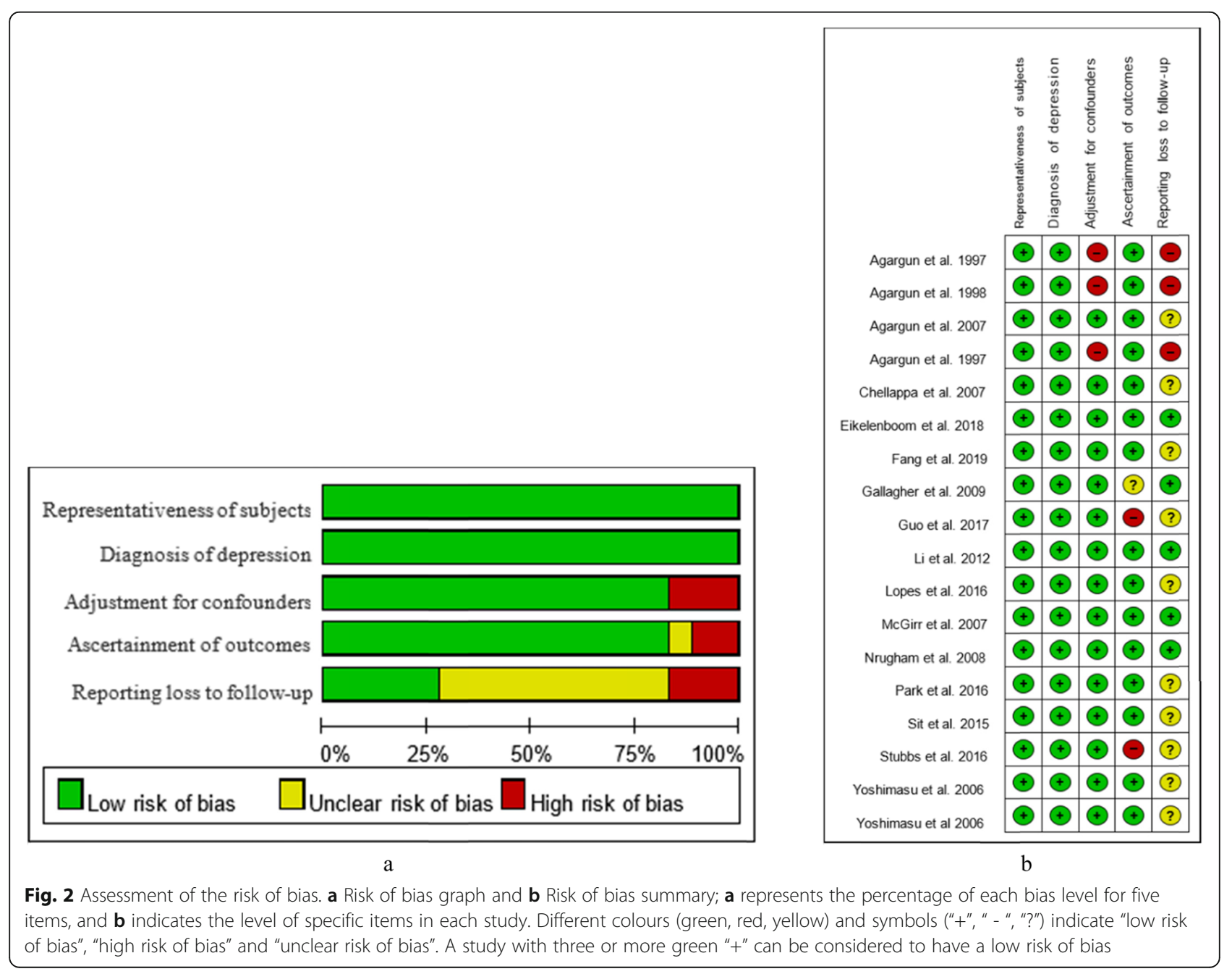




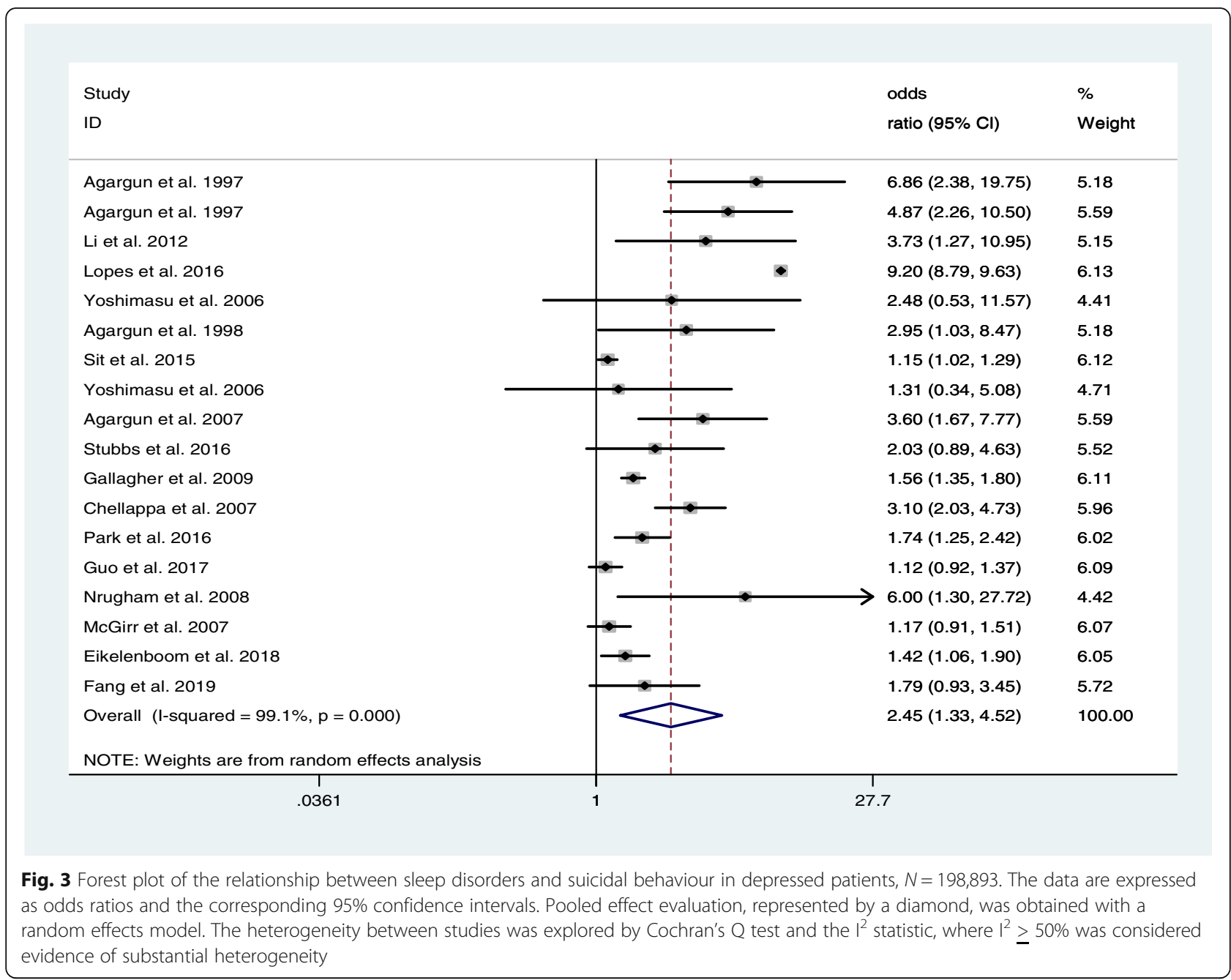

its dysfunction might lead to sleep disorders [42]. Depressed patients were observed to have reduced SWS and a decreased concentration of 5-hydroxyindole acetic acid (5-HIAA, a major metabolite of 5-HT) in cerebrospinal fluid. Benson et al. reported that the measurement of SWS in depression was closely related to serotonergic activity [43]. These results suggest that serotoninergic dysfunction might be a risk factor for sleep disorders. Furthermore, ritanserin, a specific 5-HT2 antagonist, has been confirmed to distinctly increase SWS in depression [44], which verifies the hypothesis that 5-HT plays an important role in sleep regulation. Moreover, a reduction in 5-HIAA has been found to indicate depression, modulate impulsive control and act as a risk marker for suicidal behaviour [45]. Therefore, serotonin dysfunction is presumed to be an important physiological factor for the association between sleep disorders and suicidal behaviour in depressed patients.

However, McCall et al. held that specific sleep disorders such as insomnia did not necessarily lead to suicide through serotonin. Instead, they proposed that sleep disorders destroy the function of serotonin. They found that insomnia symptoms appeared to be indirectly related to suicidal behaviours by dysfunctional beliefs and attitudes about sleep and nightmares [46]. In a clinical trial, Bernert et al. confirmed that less non-REM Stage 4 sleep and higher levels of nocturnal wakefulness were associated with suicidal behaviour in depressed patients [4]. In addition, other hypotheses, including the involvement of the hyperactive hypothalamic-pituitary-adrenal axis and the overactivity of the noradrenergic system, were also described as pathophysiological mechanisms of increased suicide risk in patients with depression and sleep disorders [18]. Because both of these hypotheses appear to be involved in the response to stressful events, causality is difficult to establish, and more evidence is needed to validate these hypotheses.

In addition to pathophysiological explanations, psychosocial factors such as unemployment, divorce and circadian rhythm disorders could directly aggravate sleep disorders in depression. However, the comorbidity among psychosocial factors, sleep disorders and 
Table 2 Subgroup meta-analysis and analysis of heterogeneity

\begin{tabular}{|c|c|c|c|c|c|c|}
\hline \multirow[t]{2}{*}{ Subgroup } & \multirow{2}{*}{$\begin{array}{l}\text { No. of } \\
\text { studies }\end{array}$} & \multirow{2}{*}{$\begin{array}{l}\text { No. of } \\
\text { subjects }\end{array}$} & \multirow[t]{2}{*}{ OR $(95 \% \mathrm{Cl})$} & \multicolumn{2}{|c|}{ Heterogeneity } & \multirow[t]{2}{*}{$P$ value } \\
\hline & & & & $\overline{I^{2}(\%)}$ & $P$ value & \\
\hline \multicolumn{7}{|l|}{ Year of publication } \\
\hline $1997 \sim 2010$ & 10 & 166,949 & 2.53 (1.75 3.66) & 76.8 & $<0.001$ & $<0.001$ \\
\hline $2010 \sim 2019$ & 8 & 31,944 & $2.10(0.805 .53)$ & 99.5 & $<0.001$ & 0.134 \\
\hline \multicolumn{7}{|l|}{ Study design } \\
\hline Retrospective & 6 & 171,176 & 1.79 (1.33 2.42) & 83.1 & $<0.001$ & $<0.001$ \\
\hline Prospective & 6 & 4856 & $2.25(1.393 .64)$ & 75.3 & 0.001 & 0.001 \\
\hline Cross-sectional & 6 & 22,861 & $2.45(0.797 .61)$ & 98.9 & $<0.001$ & 0.122 \\
\hline \multicolumn{7}{|l|}{ Sample size } \\
\hline$<1000$ & 11 & 2234 & 2.99 (1.28 6.98) & 99.2 & $<0.001$ & 0.011 \\
\hline$>1000$ & 7 & 196,659 & $1.50(1.241 .81)$ & 53.8 & 0.043 & $<0.001$ \\
\hline \multicolumn{7}{|l|}{ Age of subjects } \\
\hline Mean $<40$ & 12 & 189,712 & 2.75 (1.26 6.03) & 99.4 & $<0.001$ & 0.011 \\
\hline Mean $\geq 40$ & 6 & 9181 & $1.81(1.302 .51)$ & 73.4 & 0.002 & $<0.001$ \\
\hline \multicolumn{7}{|l|}{ Diagnostic criteria } \\
\hline ICD-10 & 2 & 1541 & $2.13(1.104 .12)$ & 43.2 & 0.185 & 0.025 \\
\hline DSM-III-R & 4 & 2681 & $4.80(2.907 .67)$ & 0 & 0.720 & $<0.001$ \\
\hline DSM-IV & 11 & 174,541 & $2.11(0.964 .65)$ & 99.4 & $<0.001$ & 0.063 \\
\hline CES-D & 1 & 20,130 & 1.12 (0.92 1.37) & - & - & 0.265 \\
\hline \multicolumn{7}{|l|}{ Diagnostic outcome } \\
\hline Major depression & 12 & 5336 & $2.92(1.425 .98)$ & 97.5 & $<0.001$ & 0.003 \\
\hline Depression & 6 & 193,557 & $1.41(1.141 .73)$ & 75.6 & 0.001 & 0.001 \\
\hline \multicolumn{7}{|l|}{ Sleep disorder type } \\
\hline Insomnia & 12 & 172,759 & $2.29(1.693 .10)$ & 86.1 & $<0.001$ & $<0.001$ \\
\hline Nightmares & 3 & 582 & 4.47 (2.00 9.97) & 0 & 0.490 & $<0.001$ \\
\hline Hypersomnia & 3 & 2914 & $2.19(0.776 .21)$ & 93.0 & $<0.001$ & 0.140 \\
\hline Other & 7 & 27,144 & $2.41(0.807 .24)$ & 99.6 & $<0.001$ & 0.117 \\
\hline \multicolumn{7}{|l|}{ Suicidal behavior type } \\
\hline Suicidal ideation & 13 & 194,419 & $2.32(1.114 .88)$ & 99.2 & $<0.001$ & 0.026 \\
\hline Suicide attempts & 7 & 193,834 & $2.41(1.454 .02)$ & 87.7 & $<0.001$ & 0.001 \\
\hline Completed suicide & 2 & 163,668 & $1.24(1.001 .53)$ & 0 & 0.445 & 0.050 \\
\hline Other & 2 & 225 & $4.19(2.826 .21)$ & 0 & 0.654 & $<0.001$ \\
\hline
\end{tabular}

OR Odds ratio, ICD-10 International classification of diseases, tenth revision, DSM The diagnostic and statistical manual of mental disorders, CES-D Center for epidemiology scale for depression

suicidal behaviours remained an open question and needed to be addressed in a large number of cases [47]. Hopelessness might partly explain this relationship. Hopelessness is common in depression and is a key form of dysfunctional cognition that can lead to chronic insomnia and is itself a potential risk factor for suicide $[9,48]$. Moreover, hopelessness can cause patients to have dysfunctional beliefs related to the hopelessness of sleep, which could aggravate the patient's depression and suicidal tendencies. Other authors have hypothesized that sleep may provide an alternative to suicide for people with depression so that they can temporarily escape problems in their daily lives. Various sleep disorders may make these patients unable to escape and evade this burden except through suicidal behaviour [49]. There is evidence that loss of sleep might impair problem solving and mood regulation in patients and thus increase the risk of impulsive behaviour and suicidal tendencies [50].

In this meta-analysis, we found that the pooled OR of nightmares was almost twice that of insomnia, and both ORs were statistically significant. A body of work strongly suggests an association between insomnia and nightmares and suicidality in depression. A 4-year 
Table 3 GRADE assessment of evidence quality

\begin{tabular}{|c|c|c|c|c|c|c|c|c|c|c|}
\hline \multicolumn{9}{|c|}{ Quality assessment } & \multirow{2}{*}{$\begin{array}{l}\text { Effect } \\
\text { Relative } \\
(95 \% \mathrm{Cl})\end{array}$} & \multirow{2}{*}{$\begin{array}{l}\text { Overall } \\
\text { quality of } \\
\text { evidence }\end{array}$} \\
\hline $\begin{array}{l}\text { No of } \\
\text { studies }\end{array}$ & Study design & $\begin{array}{l}\text { Risk of } \\
\text { bias }\end{array}$ & Inconsistency & Indirectness & Imprecision & $\begin{array}{l}\text { Publication } \\
\text { bias }\end{array}$ & $\begin{array}{l}\text { Other } \\
\text { considerations }\end{array}$ & $\begin{array}{l}\text { No of } \\
\text { subjects }\end{array}$ & & \\
\hline \multicolumn{11}{|l|}{ Overall } \\
\hline 18 & $\begin{array}{l}\text { observational } \\
\text { studies }\end{array}$ & $\begin{array}{l}\text { not } \\
\text { serious }\end{array}$ & Serious $^{a}$ & not serious & not serious & detected & $\begin{array}{l}\text { Very strong } \\
\text { association }{ }^{b}\end{array}$ & 198,893 & $\begin{array}{l}\text { OR } 2.45(1.33 \\
4.52)\end{array}$ & $\begin{array}{l}\text { ФOOO VERY } \\
\text { LOW }\end{array}$ \\
\hline \multicolumn{11}{|c|}{$\begin{array}{l}\text { Major } \\
\text { depression }\end{array}$} \\
\hline 12 & $\begin{array}{l}\text { observational } \\
\text { studies }\end{array}$ & $\begin{array}{l}\text { not } \\
\text { serious }\end{array}$ & Serious $^{a}$ & not serious & not serious & detected & $\begin{array}{l}\text { Very strong } \\
\text { association }{ }^{b}\end{array}$ & 5336 & $\begin{array}{l}\text { OR } 2.92(1.42 \\
5.98)\end{array}$ & $\begin{array}{l}\text { 円OOO VERY } \\
\text { LOW }\end{array}$ \\
\hline \multicolumn{11}{|c|}{ Depression } \\
\hline 6 & $\begin{array}{l}\text { observational } \\
\text { studies }\end{array}$ & $\begin{array}{l}\text { not } \\
\text { serious }\end{array}$ & not serious & not serious & not serious & $\begin{array}{l}\text { not } \\
\text { detected }\end{array}$ & none & 193,557 & $\begin{array}{l}\text { OR } 1.41(1.14 \\
1.73)\end{array}$ & $\begin{array}{l}\oplus \oplus O O \\
\text { LOW }\end{array}$ \\
\hline
\end{tabular}

OR Odds ratio, $\mathrm{Cl}$ Confidence interval

${ }^{a}$ The score was downgraded because substantial heterogeneity between studies was detected and could not be fully explained

${ }^{b}$ The score was upgraded because the magnitude of the effect was large (OR $>2$ based on consistent evidence from at least two studies, with no plausible confounders)

prospective observational study by $\mathrm{Li}$ et al. reported that in depressed outpatients who had been relieved of symptoms, the one-year prevalence of frequent insomnia at baseline and follow-up was 38.0 and 19.3\%, respectively, and the corresponding incidence of nightmares was 24.0 and $9.3 \%$, respectively. After controlling for age, marriage and psychiatric comorbidity, only nightmares were closely related to suicidal ideation [22]. Agargun et al. obtained a similar finding [35]. This result might be explained by a higher prevalence of and deeper psychological distress related to nightmares in suicidal patients.

Antidepressants, such as selective serotonin reuptake inhibitors (SSRIs) and serotonin-norepinephrine reuptake inhibitors (SRNIs), have been independently confirmed to be associated with nightmare recurrence after adjustment for confounding variables. Thus, depressed patients who take these medications are inevitably more likely to have nightmares [51]. Agargun et al. suggested that nightmares reflect a negative dream effect associated with deeper levels of selfcriticism and self-blaming and make patients feel worse in the morning than later in the day and that the presence of terminal insomnia might play an important role in preventing morning depression [35].

Through an integrated motivational-volitional (IMV) model of suicidal behaviour, Russell et al. demonstrated that the relationship between insomnia and suicidal ideation was entirely governed by perceptions of defeat and entrapment. Nightmares were indirectly linked to suicidal ideation through perceptions of defeat and entrapment, but further research is required to untangle the link between insomnia/nightmares and defeat [52]. Overall, we did not find an independent predictive effect of hypersomnia on suicidal behaviour. Epidemiological data showed that respondents with simultaneous sleep disorders had a higher rate of suicide attempts than those with only hypersomnia [53]. Because daytime hypersomnia or fatigue might also be a symptom of depression, a careful exploration of hypersomnia in depressed patients is consistently recommended [48].

Another interesting outcome in this study was that depressed patients were at higher risk for the association between sleep disorders and suicide attempt, followed by the association between sleep disorders and suicidal ideation and completed suicide. This result is consistent with the findings of Malik et al. Remarkably, the pooled OR of each type of suicidal behaviour in our study was higher than that in their studies. This result might be related to interference from the many other mental illnesses they included, such as affective disorder, panic disorder, and post-traumatic stress disorder [54]. The process driving the difference between the three abovementioned suicidal behaviours and the risk of sleep disorders is unclear. As mentioned above, existing data suggest that nightmares, rather than other sleep disorders, have a stronger association with the risk of suicidal behaviour $[55,56]$. In contrast, nightmares have been found to be more common among patients who have attempted suicide [35]. It might be suggested that nightmares could be considered an important indicator of suicide attempts in depressed patients [57]. In addition, sleep disorders were found to increase the risk of completed suicide, but the effect values were on the margins of statistical significance. Considering that few included studies could be combined, our results require further analysis after expanding the sample size.

Preventive interventions for suicidal behaviour have been poorly developed, especially for patients with depression or comorbidities with other mental illnesses [58]. Problem-solving therapy (PST) and cognitive behavioural therapy (CBT), as evidenced by a Cochrane Library 
review, effectively reduced the proportion of repeat selfinjury, suicidal ideation and depressive symptoms within 12 months. However, the quality of this evidence was graded as moderate to low [59]. A study by Sayal et al. demonstrated that recruitment for a randomized controlled trial (RCT) of remotely delivered problem-solving CBT for young people with depression and repeated selfharm or suicide was not feasible because this population was unwilling to accept this intervention. They also found that clinician assessment following suicidal behaviour presentation mainly identified individuals with severe rather than mild-moderate depression [60].

In a study by Nadorff et al., the duration of nightmares was related to a higher risk of suicide. This finding might contribute to improving clinical practice [61]. In the past, clinicians were told not to use treatment related to nightmares, such as image rehearsal therapy, for people who were suicidal because the nightmares might worsen before they improve [62]. However, Nadorff et al. suggested that as long as appropriate precautions are taken (such as setting up a safety plan, hospitalization or frequent outpatient visits), it might be appropriate to use nightmare-related treatment for individuals at risk of suicide [63]. Moreover, some medications, such as clozapine and lithium, were confirmed to have anti-suicidal effects, and the latter had a beneficial effect on sleep. However, no mechanism was proposed for this drug to reduce suicidal behaviour by improving sleep $[47,58]$.

Although our outcomes showed significant differences (the ORs ranged from 1.24 to 2.41 for sleep disorders and 4.47 for nightmares), our results are still trustworthy due to the following factors. First, we established a rigorous search strategy to reduce any artificial omissions. Second, we adopted NOS to evaluate the methodological quality of each of the included studies and used the GRADE approach to evaluate the quality of the evidence. Third, most of the ORs we included were adjusted ORs, and through subgroup analysis and meta-regression, we found a partial source of heterogeneity among studies.

On the basis of statistical significance, this metaanalysis confirmed that the risk of suicidal behaviour across depressed patients was 2.45 times higher if they presented with sleep disorders than in patients without sleep disorders. This result is useful in clinical practice because in most areas, factors that increase the risk by a $10 \%$ threshold can be extremely important. However, regarding clinical significance, our findings need to be interpreted cautiously because of the low base rate of suicidal behaviour [63]. Our findings showed that patients with more severe depression have a higher risk of suicidal behaviour if they have sleep disorders. However, if the original study inadvertently included patients with bipolar disorder and these studies were mistakenly assigned to the "depression" group when the authors did not indicate that the subjects had major depression, this may have led to confusion in the outcomes of our two subgroups. In addition, previous studies confirmed that sleep disorders might be a symptom of major depression in patients $[64,65]$. This makes it challenging for us to analyse sleep disorders and unipolar depression and may have led to an underestimation of the outcomes. Furthermore, considering that most of the participants in these included studies had unipolar depression, the discussion of this study focused on patients with unipolar depression and might be not applicable to studies involving other psychiatric disorders with depressive symptoms, such as bipolar disorder. In short, the present findings indicate a need for more powerful evidence. However, to clarify the conclusions, we must overcome the methodological limitations of existing articles to indicate whether the included participants have unipolar depression or bipolar disorder.

Furthermore, other limitations should be taken into account. First, all of the included studies were observational; thus, causality was difficult to establish. Second, there was still some heterogeneity that could not be explained, and the lack of uniform diagnostic criteria might reduce the comparability between studies. Third, because the data from many studies were not available, we did not have all the data from the 18 studies to summarize them. Thus, our results were an aggregation of potentially unstable estimates that were unlikely to be replicated. A more robust approach is needed to validate our results.

\section{Conclusions}

This systematic review and meta-analysis distinctly indicated a link between sleep disorders and suicidal behaviour in depression. Insomnia and nightmares, in particular, were found to significantly increase the risk of suicide in depressed patients. Further research is needed to clarify the specific mechanisms of sleep disorders on suicidal behaviour, and more well-designed trials are needed to reduce the risk of suicide by improving sleep quality in depressed patients.

\section{Supplementary information}

Supplementary information accompanies this paper at https://doi.org/10. 1186/s12888-019-2302-5.

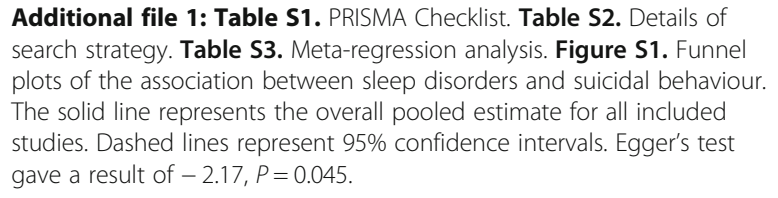

Additional file 1: Table S1. PRISMA Checklist. Table S2. Details of search strategy. Table S3. Meta-regression analysis. Figure S1. Funnel plots of the association between sleep disorders and suicidal behaviour. The solid line represents the overall pooled estimate for all included studies. Dashed lines represent 95\% confidence intervals. Egger's test gave a result of $-2.17, P=0.045$.

\section{Abbreviations}

CBT: Cognitive behavioural therapy; CES-D: Center for Epidemiology Scale for Depression; Cl: Confidence interval; DSM: The Diagnostic and Statistical 
Manual of Mental Disorders; GRADE: Grading of Recommendations Assessment, Development and Evaluation; ICD-10: International Classification of Diseases, Tenth Revision; IMV: Integrated motivational-volitional; IOM: Institute of Medicine; MDD: Major depressive disorder; MeSH: Medical Subject Headings; NOS: Newcastle-Ottawa Scale; OR: Odds ratio; PRISMA: Systematic and Meta-analytical Preferred Reporting Program; PST: Problem-solving therapy; RCT: Randomized controlled trial; REM: Rapid eye movement sleep; RR: Relative risk; SRNI: Serotonin-norepinephrine reuptake inhibitors; SSRI: Selective serotonin reuptake inhibitors; SWS: Slow wave sleep; WHO: World Health Organization

\section{Acknowledgements}

We thank all the authors who provided these original studies and detailed data.

\section{Authors' contributions}

XW and HX designed the study and the search strategy. XW and SC performed the study selection, quality assessment and data analysis. XW wrote the first draft. HX critically revised the manuscript and approved the final version as submitted. All authors read and approved the final manuscript.

\section{Authors' information}

XFW, SXC, HLX, Department of Social Medicine and Health Management, Xiangya School of Public Health, Central South University, Changsha, Hunan Province, China.

\section{Funding}

No funding was received for this systematic review.

\section{Availability of data and materials}

The data sets supporting the conclusions of this article are included within the article and its supplementary materials.

\section{Ethics approval and consent to participate}

Not applicable.

\section{Consent for publication}

All authors agree to publication.

\section{Competing interests}

The authors declare that they have no competing interests.

Received: 12 April 2019 Accepted: 20 September 2019 Published online: 17 October 2019

\section{References}

1. Wilcox HC, Wyman PA. Suicide prevention strategies for improving population health. Child Adolesc Psychiatr Clin N Am. 2016;25(2):219-33 (1558-0490 (Electronic)).

2. Fleischmann A, Arensman E, Berman A, Carli V, De Leo D, Hadlaczky G, Howlader S, Vijayakumar L, Wasserman D, Saxena S. Overview evidence on interventions for population suicide with an eye to identifying bestsupported strategies for LMICs. Glob Ment Health (Camb). 2016;3:e5 (20544251 (Print)).

3. Wang SY, Li Y, Chi GB, Xiao SY, Ozanne-Smith J, Stevenson M, Phillips MR. Injury-related fatalities in China: an under-recognised public-health problem. Lancet. 2008;372(9651):1765-73 (1474-547X (Electronic)).

4. Bernert RA, Luckenbaugh DA, Duncan WC, Iwata NG, Ballard ED, Zarate CA. Sleep architecture parameters as a putative biomarker of suicidal ideation in treatment-resistant depression. J Affect Disord. 2017;208:309-15.

5. Naifeh JA, Ursano RJ, Kessler RCA, Zaslavsky AM, Nock MK, Dempsey CL, Bartolanzo D, Ng THH, Aliaga PA, Zuromski KL et al. Transition to suicide attempt from recent suicide ideation in U.S. Army soldiers: results from the Army Study to Assess Risk and Resilience in Servicemembers (Army STAR RS). LID - https://doi.org/10.1002/da.22870 [doi]. Combined effects of depression and anxiety on suicide: a case-control psychological autopsy study in rural China. (1520-6394 (Electronic)).

6. Wilks CR, Morland LA, Dillon KH, Mackintosh MA, Blakey SM, Wagner HR, Elbogen EB. Anger, social support, and suicide risk in U.S. military veterans. J Psychiatr Res. 2019;109:139-44 (1879-1379 (Electronic)).
7. Zhang J, Liu X, Fang L. Combined effects of depression and anxiety on suicide: A case-control psychological autopsy study in rural China. Psychiatry Res. 2019;271(1872-7123):370-3.

8. Oquendo MA, Malone KM, Mann JJ. Suicide: risk factors and prevention in refractory major depression. Depress Anxiety. 1997;5(4):202-11 (10914269 (Print)).

9. Coryell W, Young EA. Clinical predictors of suicide in primary major depressive disorder. J Clin Psychiatry. 2005;66(4):412-7 (0160-6689 (Print)).

10. Eikelenboom M, Beekman ATF, Penninx BWJH, Smit JH. A 6-year longitudinal study of predictors for suicide attempts in major depressive disorder. Psychol Med. 2018;49(6):911-21.

11. Yang $L$, Zhao $Y$, Wang $Y$, Liu L, Zhang $X$, Li B, Cui R. The effects of psychological stress on depression. Curr Neuropharmacol. 2015;13(4): 494-504.

12. Smith K. Mental health: a world of depression. Nature. 2014;515(7526):181 (1476-4687 (Electronic)).

13. Gibbons JS, Horn SH, Powell JM, Gibbons JL. Schizophrenic patients and their families. A survey in a psychiatric service based on a DGH unit. Br J Psychiatry. 1984;144(1):70-7.

14. Vuorilehto M, Valtonen HM, Melartin T, Sokero P, Suominen $K$, Isometsa ET. Method of assessment determines prevalence of suicidal ideation among patients with depression. Eur Psychiatry. 2014;29(6):338-44 (1778-3585 (Electronic)).

15. Li H, Luo X, Ke X, Dai Q, Zheng W, Zhang C, Cassidy RM, Soares JC, Zhang $X$, Ning Y. Major depressive disorder and suicide risk among adult outpatients at several general hospitals in a Chinese Han population. PLoS One. 2017;12(10):e0186143.

16. Simon GE, VonKorff M, Piccinelli M, Fullerton C, Ormel J. An international study of the relation between somatic symptoms and depression. $\mathrm{N}$ Engl J Med. 1999;341(18):1329-35 (0028-4793 (Print)).

17. Tsuno N, Besset A, Ritchie K. Sleep and depression. J Clin Psychiatry. 2005; 66(10):1254-69 (0160-6689 (Print)).

18. Chellappa SL, Araujo JF. Sleep disorders and suicidal ideation in patients with depressive disorder. Psychiatry Res. 2007;153(2):131-6.

19. Pan D, Xu Y, Zhang L, Su Q, Chen M, Li B, Xiao Q, Gao Q, Peng X, Jiang B, et al. Gene expression profile in peripheral blood mononuclear cells of postpartum depression patients. Sci Rep. 2018;8:10139 (2045-2322 (Electronic)).

20. Zadka L, Dziegiel P, Kulus M, Olajossy M. Clinical phenotype of depression affects interleukin-6 synthesis. J Interferon Cytokine Res. 2017;37(6):231-45 (1557-7465 (Electronic)).

21. Fang X, Zhang C, Wu Z, Peng D, Xia W, Xu J, Wang C, Cui L, Huang J, Fang $Y$. The association between somatic symptoms and suicidal ideation in Chinese first-episode major depressive disorder. J Affect Disord. 2019;245:17-21.

22. Li SX, Lam SP, Chan JW, Yu MW, Wing YK. Residual sleep disturbances in patients remitted from major depressive disorder: a 4-year naturalistic follow-up study. Sleep. 2012;35(8):1153-61.

23. Gallagher AM, De Vries F, Tylee AT, Lader MH, Donoghue J, Cockle SM, Van Staa TP, Nutt DJ. The risk of suicide and suicidal ideation in depressed patients with sleep disturbance. Eur Neuropsychopharmacol. 2009;19:S379-80.

24. Moher D, Shamseer L, Clarke M, Ghersi D, Liberati A, Petticrew M, Shekelle P, Stewart LA. Preferred reporting items for systematic review and metaanalysis protocols (PRISMA-P) 2015 statement. Syst Rev. 2015;4:1 (2046-4053 (Electronic)).

25. Margulis AV, Pladevall M, Riera-Guardia N, Varas-Lorenzo C, Hazell L, Berkman ND, Viswanathan M, Perez-Gutthann S. Quality assessment of observational studies in a drug-safety systematic review, comparison of two tools: the Newcastle-Ottawa Scale and the RTI item bank. Clin Epidemiol. 2014;6:359-68 (1179-1349 (Print)).

26. Guyatt G, Oxman AD, Akl EA, Kunz R, Vist G, Brozek J, Norris S, Falck-Ytter Y, Glasziou P, DeBeer H, Jaeschke R, et al. GRADE guidelines: 1. IntroductionGRADE evidence profiles and summary of findings tables. J Clin Epidemiol. 2011:64(4):383-94 (1878-5921 (Electronic)).

27. Guyatt GH, Oxman AD, Schunemann HJ, Tugwell P, Knottnerus A. GRADE guidelines: a new series of articles in the Journal of Clinical Epidemiology. J Clin Epidemiol. 2011;64(4):380-2 (1878-5921 (Electronic)).

28. Agargun MY, Kara H, Solmaz M. Sleep disturbances and suicidal behavior in patients with major depression. J Clin Psychiatry. 1997;58(6):249-51.

29. Agargun MY, Kara H, Solmaz M. Subjective sleep quality and suicidality in patients with major depression. J Psychiatr Res. 1997;31(3):377-81. 
30. Lopes MC, Boronat AC, Wang YP, Fui L. Sleep complaints as risk factor for suicidal behavior in severely depressed children and adolescents. CNS Neurosci Ther. 2016;22(11):915-20.

31. Yoshimasu K, Sugahara H, Akamine M, Kondo T, Fujisawa K, Tokunaga S, Kiyohara C, Miyashita K, Kubo C. Sleep disorders and suicidal ideation in Japanese patients visiting a psychosomatic clinic in a university hospital. Sleep Biol Rhythms. 2006;4(2):137-43.

32. Ağargün MY, Çilli AS, Kara H, Tarhan N, Kincir F, Öz H. Repetitive and frightening dreams and suicidal behavior in patients with major depression. Compr Psychiatry. 1998:39(4):198-202.

33. Sit D, Luther J, Buysse D, Dills JL, Eng H, Okun M, Wisniewski S, Wisner KL. Suicidal ideation in depressed postpartum women: associations with childhood trauma, sleep disturbance and anxiety. J Psychiatr Res. 2015;66-67:95-104.

34. Yoshimasu K, Sugahara H, Tokunaga S, Akamine M, Kondo T, Fujisawa K, Miyashita K, Kubo C. Gender differences in psychiatric symptoms related to suicidal ideation in Japanese patients with depression. Psychiatry Clin Neurosci. 2006;60(5):563-9.

35. Agargun MY, Besiroglu L, Cilli AS, Gulec M, Aydin A, Inci R, Selvi Y. Nightmares, suicide attempts, and melancholic features in patients with unipolar major depression. J Affect Disord. 2007;98(3):267-70.

36. Stubbs B, Wu YT, Prina AM, Leng Y, Cosco TD. A population study of the association between sleep disturbance and suicidal behaviour in people with mental illness. J Psychiatr Res. 2016;82:149-54.

37. Park SC, Lee MS, Hahn SW, Si TM, Kanba S, Chong MY, Yoon CK, Udomratn P, Tripathi A, Sartorius N et al. Suicidal thoughts/acts and clinical correlates in patients with depressive disorders in Asians: results from the REAP-AD study. Acta Neuropsychiatr. 2016;28(6):337-45.

38. Guo L, Xu Y, Deng J, Huang J, Huang G, Gao X, Li P, Wu H, Pan S, Zhang $\mathrm{WH}$ et al. Association between sleep duration, suicidal ideation, and suicidal attempts among Chinese adolescents: the moderating role of depressive symptoms. J Affect Disord. 2017;208:355-62.

39. Nrugham L, Larsson B, Sund AM. Specific depressive symptoms and disorders as associates and predictors of suicidal acts across adolescence. $J$ Affect Disord. 2008;111(1):83-93.

40. McGirr A, Renaud J, Seguin M, Alda M, Benkelfat C, Lesage A, Turecki G. An examination of DSM-IV depressive symptoms and risk for suicide completion in major depressive disorder: a psychological autopsy study. J Affect Disord. 2007;97(1-3):203-9.

41. Staner L, Kempenaers C, Simonnet MP, Fransolet L, Mendlewicz J. 5-HT2 receptor antagonism and slow-wave sleep in major depression. Acta Psychiatr Scand. 1992;86(2):133-7 (0001-690X (Print)).

42. Fau JM, Touret M. Indolamines and sleep: 5-HT or 5-HTP? Schweiz Rundsch Med Prax. 1988;77(34A):6-9.

43. Benson KL, Faull KF, Zarcone VP Jr. The effects of age and serotonergic activity on slow-wave sleep in depressive illness. Biol Psychiatry. 1993;33(1112):842-4 (0006-3223 (Print)).

44. Solomon RA, Sharpley AL, Cowen PJ. Increased slow wave sleep with 5-HT2 receptor antagonists: detection by ambulatory EEG recording and automatic sleep stage analysis. J Psychopharmacol. 1989;3(3):125-9 (02698811 (Print)).

45. Linnoila VM, Virkkunen M. Aggression, suicidality, and serotonin. J Clin Psychiatry. 1992;53(Suppl):46-51 (0160-6689 (Print)).

46. McCall WV, Blocker JN, D’Agostino R Jr, Kimball J, Boggs N, Lasater B, Rosenquist PB. Insomnia severity is an indicator of suicidal ideation during a depression clinical trial. Sleep Med. 2010;11(9):822-7 (1878-5506 (Electronic)).

47. Norra C, Richter N, Juckel G. Sleep disturbances and suicidality: a common association to look for in clinical practise and preventive care. EPMA J. 2011; 2(3):295-307 (1878-5085 (Electronic)).

48. Espie CA, Inglis SJ, Harvey L, Tessier S. Insomniacs' attributions. psychometric properties of the Dysfunctional Beliefs and Attitudes about Sleep Scale and the Sleep Disturbance Questionnaire. J Psychosom Res. 2000;48(2):141-8 (0022-3999 (Print)).

49. Littlewood DA-O, Gooding PA-O, Kyle SD, Pratt D, Peters S. Understanding the role of sleep in suicide risk: qualitative interview study. BMJ Open. 2016; 6(8):e012113 (2044-6055 (Electronic)).

50. Anderson C, Platten CR. Sleep deprivation lowers inhibition and enhances impulsivity to negative stimuli. Behav Brain Res. 2011;217(2):463-6 (18727549 (Electronic)).

51. Sjostrom N, Waern M, Hetta J. Nightmares and sleep disturbances in relation to suicidality in suicide attempters. Sleep. 2007;30(1):91-5 (01618105 (Print)).
52. Russell K, Rasmussen S, Hunter SC. Insomnia and nightmares as markers of risk for suicidal ideation in young people: investigating the role of defeat and entrapment. J Clin Sleep Med. 2018;14(5):775-84.

53. Soehner AM, Kaplan KA, Harvey AG. Prevalence and clinical correlates of cooccurring insomnia and hypersomnia symptoms in depression. J Affect Disord. 2014;167:93-7 (1573-2517 (Electronic)).

54. Malik S, Kanwar A, Sim LA, Prokop LJ, Wang Z, Benkhadra K, Murad MH. The association between sleep disturbances and suicidal behaviors in patients with psychiatric diagnoses: a systematic review and meta-analysis. Syst Rev. 2014;3(2046-4053 (Electronic)):18.

55. Liu X, Buysse DJ. Sleep and youth suicidal behavior: a neglected field. Curr Opin Psychiatry. 2006;19(3):288-93.

56. Bernert R, Reeve J, Perlis MIL, Joiner TE. Insomnia and nightmares as predictors of elevated suicide risk among patients seeking admission to emergency mental health facility. Sleep. 2009;32:A365-6.

57. Sher L, Grunebaum MF, Burke AK, Chaudhury S, Mann JJ, Oquendo MA. Depressed multiple-suicide-attempters - a high-risk phenotype. Crisis. 2017; 38(6):367-75 (2151-2396 (Electronic)).

58. Oquendo MA, Stanley B, Ellis SP, Mann JJ. Protection of human subjects in intervention research for suicidal behavior. Am J Psychiatry. 2004;161(9): 1558-63 (0002-953X (Print)).

59. Hawton K, Witt KG, Taylor Salisbury TL, Arensman E, Gunnell D, Hazell P, Townsend $E$, van Heeringen K. Psychosocial interventions for self-harm in adults. Cochrane Db Syst Rev. 2016;(5) (1469-493X (Electronic)).

60. Sayal K, Roe J, Ball H, Atha C, Kaylor-Hughes C, Guo B, Townsend E, Morriss R. Feasibility of a randomised controlled trial of remotely delivered problem-solving cognitive behaviour therapy versus usual care for young people with depression and repeat self-harm: lessons learnt (e-DASH). BMC Psychiatry. 2019;19(1):42 (1471-244X (Electronic)).

61. Nadorff MR, Nazem S, Fiske A. Insomnia symptoms, nightmares, and suicide risk: duration of sleep disturbance matters. Suicide Life Threat Behav. 2013; 43(2):139-49.

62. Talbot M. Nightmare scenario: can we learn to rewrite our bad dreams? 2009;(0028-792X (Print)):43-51.

63. Franklin JC, Ribeiro JD, Fox KR, Bentley KH, Kleiman EM, Huang X, Musacchio KM, Jaroszewski AC, Chang BP, Nock MK. Risk factors for suicidal thoughts and behaviors: A meta-analysis of 50 years of research. Psychol Bull. 2017; 143(2):187-232.

64. Zimmermann C, Pfeiffer H. Sleep disorders in depression. Suggestions for a therapeutic approach. Nervenarzt. 2007;78(1):21-30.

65. Maes M, Meltzer HY, Suy E, Minner B, Calabrese J, Cosyns P. Sleep disorders and anxiety as symptom profiles of sympathoadrenal system hyperactivity in major depression. J Affect Disord. 1993;27(3):197-207.

\section{Publisher's Note}

Springer Nature remains neutral with regard to jurisdictional claims in published maps and institutional affiliations.

Ready to submit your research? Choose BMC and benefit from:

- fast, convenient online submission

- thorough peer review by experienced researchers in your field

- rapid publication on acceptance

- support for research data, including large and complex data types

- gold Open Access which fosters wider collaboration and increased citations

- maximum visibility for your research: over $100 \mathrm{M}$ website views per year

At BMC, research is always in progress.

Learn more biomedcentral.com/submissions 